\title{
POLYVICTIMIZATION \& POLYTRAUMATIZATION: LEGAL AND PSYCHOLOGICAL ASPECTS
}

\author{
Raitis Eglītis \\ University of Latvia, Faculty of Pedagogy, Psychology and Art, \\ Riga Centre of Psychiatry and Addiction Disorders
}

Keywords: polyvictimization, polytraumatization, multitype maltreatment, cumulative harm, forensic assessment.

\begin{abstract}
Summary
Polyvictimization is experience of multiple, different kind victimizations that range from child maltreatment to school bullying and beyond. Polytraumatization includes trauma that are not limited to interpersonal abuse, for example, car accidents, natural disasters etc. These concepts are in turn related to cumulative harm and multitype maltreatment which are discussed later in the article. Polyvictimization and polytraumatization highlights the shift in abuse research and practice from single trauma to multiple trauma analysis which significantly impacts forensic and clinical judgment on causality of post-traumatic reactions.

On the other hand, legal professionals in different countries still ask mental health practitioners to identify specific emotional consequences that are linked to specific civil and/or criminal case. Whether it is called psychological damage, psychological injury, sequela etc. - legal specialists want and need to prove causal relations between wrongful act and psychological injury. Unfortunately, it is almost impossible to make a strict judgment on sequela causality if polyvictimization is identified.

The current article explains several theoretical notions regarding polyvictimization and emphasizes implications that need to be taken in to account when conducting abuse research and clinical and/or forensic victim assessment. Latvian legal system and practical problems in forensic psychological and psychiatric expertise is briefly discussed.
\end{abstract}

\section{Introduction}

When suspicion of child abuse and/or maltreatment has emerged, people in Latvia and other countries can report the possible crime and investigation takes place. Section 174 of Criminal Law of the Republic of Latvia [1] states that "For a person who commits cruel or violent treatment of a minor, if physical or mental suffering has been inflicted [...] the applicable punishment is the deprivation of liberty for a period of up to three years or temporary deprivation of liberty, or community service, or a fine and with probationary supervision for a period of up to three years". In psychological terms this means that if forensic psychologist and/or forensic psychiatrist identifies minor psychological injury (mental suffering) which is causally related to child abuse, then the suspect can be punished. Section 126 and 125 of the same law [1] states that for an intentional infliction of moderate bodily injury and severe bodily injury respectively person can be sentenced as well. From this perspective physical injuries are equalled with mental trauma and psychiatric disturbances [2] and the identification of latter two is usually falling in the competency of complex forensic psychiatric and forensic psychological assessment. It thus can be concluded that different sections of Criminal Law of the Republic of Latvia deal with as it may seem a simple question - whether or not crime A has produced consequences B. If the crime has produced consequences (mental suffering, mental trauma and/or psychiatric disturbances) - then the person is accused and can be sentenced, if not - case is closed. The problem is that indisputable trauma symptom causation following a wrongful act can be observed only in handful of cases when experts have a well-documented history of victims' adequate social functioning and social adaptation prior to crime. If in similar cases significant decline of persons social adaptation and/or social function emerges post-crime, then it can indeed be concluded that crime A has produced consequences B. Unfortunately, everyday experience shows that a lot of the victims prior to crime have suffered other traumas, stressful life events and/or adverse childhood experiences. For example, some of them have been in and out of orphanages or foster families, some of them are victims of school bullying, others have previously been victims of crime so on. And these are the most difficult situations for the forensic examiner because it is impossible to zoom-in 
or evaluate the impact of single event (crime) ignoring other trauma that have happened prior to it.

The aim of the study. Indications - this article is aimed for mental health and legal professionals who have to make decisions about victim psychological damage after wrongful acts. Several psychological concepts as well as practical difficulties are introduced and some of the problem solutions are suggested.

\section{Case example}

The author assessed a fourteen-year-old girl who was a victim of repeated physical abuse in the family. When during the interview she spoke about her parents, she showed signs of anxiety, depression and anger which matched mental suffering as mentioned in the section 174 of the criminal law. But later in the conversation she started to open up about beatings in school of which nobody was aware of. And again - signs of anxiety, depression and anger were observed which in turn could also be defined as mental suffering. In this case event $\mathrm{A}$ and event $\mathrm{B}$ altogether produced the consequences $\mathrm{C}$ and a separate, strictly causal link from the symptoms to one of the events is scientifically impossible to make. Adding to that if we are not aware of school beatings, we could falsely make a conclusion that observed symptoms reach the intensity of mental trauma (moderate bodily injury) as mentioned in section 126 of the criminal law and thus harsher sentence for the abusers in family is possible. Cases like these are common in Latvia which is reflected in statistics regarding rehabilitation of abused children [3] - from total of 1953 victims that officially got psychological treatment in 2018, 501 suffered at least two or more abuse/maltreatment types. And this is highlighting the problem - from one side legal notions ask a "simple" causal yes/no question about the psychological damage, but on the other hand psychological and psychiatric researchers and practitioners for the last 15-20 years emphasize that it is unacceptable to take one event out of the context and evaluate its impact on a person's mental state. One of the most known research supporting this belief was The Adverse childhood experiences study [4] in 1998 which showed shocking numbers of different victimizations and maltreatment people experience during lifetime and their cumulative burden to mental health. But how to deal with this discrepancy between legal and psychological/ psychiatric community? Mental health professionals since 1998 continue to conduct research on the topic of multiple trauma which is gaining more momentum every year. This can be seen by conducting a keyword "polyvictimization" search in Web of Science (2007-2019) which shows that from 1 study in 2007 the number of published papers regarding the topic in 2019 has reached 58 . The growing number of researches has evolved in several theories and concepts for better understanding of post-trauma symptom development. One of the key concepts is multi-type maltreatment [5] which is the experience of at least two or more maltreatment forms. Why is this important in assessment, research and investigation? Because the more the types of maltreatment/abuse someone has experienced, the more it is possible that he/she will develop diverse trauma symptoms. And to make matters worse a person can suffer from maltreatment which is done by different people and that similarly as in the case example above restricts categorical judgement about event A causing consequences B. Broader term is polyvictimization [6] which includes not only experience of different type maltreatment, but also other interpersonal traumas such as school bullying, exposure to family violence etc. If multi-type maltreatment and/or polyvictimization appear prior to investigation in process they can also significantly influence the mental state of the victim. Polytraumatization [7] is even broader term than polyvictimization, because it includes not only cases of victimization, but also impersonal trauma such as car accidents, natural disasters and others which can also lead to significant impact of victim's mental state. And last but not least - cumulative harm [8] - it is an ongoing trauma on a background of previous multi-type maltreatment and/ or polyvictimization. Similarly, with previously mentioned constructs when cumulative harm is identified it is impossible to isolate single trauma and draw conclusions about the impact that it has on psychological outcomes.

To sum up the psychological discoveries it can be said that the polyvictimization, polytraumatization and related constructs are crucial factors in explaining the development of post-crime trauma symptoms. Forensic practitioners should be aware of these concepts to deliberately ask their examinees questions about lifetime traumas unrelated to civil and/or criminal investigation in process in order to obtain broader perspective on victim's post-traumatic state.

\section{Conclusion}

It can be concluded that clinical purpose of a real-life victim assessment can differ from requirements of legal system. Lack of psychological knowledge about multi-type maltreatment, polyvictimization, polytraumatization and cumulative harm can lead to severe legal consequences. Some examples are analysed in this article, some of them are recently mentioned elsewhere [9]. When these conditions appear in practice the best that experts can do is to describe the mental/psychological state of the victim during the assessment and explain the interplay between different factors that could have caused symptoms that are observed. Besides that, mental health professionals should deliberately 
ask questions about victim's lifetime traumas unrelated to current civil and/or criminal investigation to obtain broader perspective on his/her post-traumatic state. Specialists can adopt and construct specific measures which are dealing with these issues, for example, Juvenile Victimization Questionnaire [6], Stressful Life Events Screening Questionnaire [10] and others. If the reader faces similar problems, it is also important to educate the person directing the proceedings about the impact of multiple trauma on development of psychological injury.

\section{References}

1. Criminal law of the Republic of Latvia. https://likumi.lv/ta/en/en/id/88966-the-criminal-law

2. On the procedures for the coming into force and application of the Criminal law of the Republic of Latvia. Annex 3.

https://likumi.lv/ta/en/en/id/50539-on-the-procedures-for-thecoming-into-force-and-application-of-the-criminal-law

3. Overview of rehabilitation tendencies of persons suffering from abuse in 2018. http://www.lm.gov.lv/lv/publikacijas-petijumiun-statistika/statistika/valsts-statistika-socialo-pakalpojumuun-socialas-palidzibas-joma/gada-dati/par-2018-gadu

4. Felitti V, Anda R, Nordenberg D, et al. Relationship of childhood abuse and household dysfunction to many of the leading causes of death in adults. Am J Prev Med 1998;14(4):245-258.

https://doi.org/10.1016/S0749-3797(98)00017-8

5. Higgins D, McCabe M. Parent perceptions of maltreatment and adjustment in children. J Fam Stud 1998;4(1):53-76. https://doi.org/10.5172/jfs.4.1.53

6. Finkelhor D, Ormrod R, Turner H, Hamby S. Measuring polyvictimization using the Juvenile victimization questionnaire. Child Abuse Negl 2005;29(11):1297-1312. https://doi.org/10.1016/j.chiabu.2005.06.005

7. Gustafsson P, Nilsson D, Svedin C. Polytraumatization and psychological symptoms in children and adolescents. Eur Child Adolesc Psychiatry 2009;18(5):274-283.

https://doi.org/10.1007/s00787-008-0728-2

8. Gillingham P, Bromfield L, Higgins D. Cumulative harm and indicators of chronic child maltreatment. Developing practice 2007;(19):34-42.

9. Bailey T, Rocchio L. Evaluating the effects of repeated psychological injury: an introduction to the special issue. Psychol Inj Law 2020;13(2):105-108. https://doi.org/10.1007/s12207-020-09386-7

10. Goodman L, Corcoran C, Turner K, Yuan N, Green B. Assessing traumatic event exposure: general issues and preliminary findings for the Stressful life events screening questionnaire. J Trauma Stress 1998;11(3):521-542. https://doi.org/10.1023/A:1024456713321

\section{POLIVIKTIMIZACIJA IR POLITRAUMATIZACIJA: TEISINIAI IR PSICHOLOGINIAI ASPEKTAI R. Eglītis}

Raktažodžiai: poliviktimizacija, politraumatizacija, ịvairialypis netinkamas elgesys, kumuliacinė žala, teismo ekspertizè.

Santrauka

Poliviktimizacija - tai daugelio skirtingų viktimizacijų patirtis, pradedant nuo netinkamo elgesio su vaikais, baigiant patyčiomis mokykloje ir kitur. Politraumatizacija suvokiama kaip trauma, kuri neapsiriboja vien tik tarpasmeniniu smurtu, - jos pavyzdžiu gali būti autoịvykiai, stichinès nelaimès ir pan. Šios sąvokos savo ruožtu susijusios su kumuliacine žala ir įvairialypiu netinkamu elgesiu, aptariamu straipsnyje. Poliviktimizacija ir politraumatizacija išryškina smurto tyrimų ir praktikos poslinkị nuo vienos traumos prie dauginès traumos analizès, o tai turi reikšmingos įtakos teismo psichiatrijos ir klinikiniams sprendimams dẻl potrauminių reakcijų priežastingumo. Kita vertus, ịvairių šalių teisès specialistai vis dar prašo psichikos sveikatos specialistų nustatyti specifines emocines pasekmes, susijusias su konkrečia civiline ir (arba) baudžiamaja byla. Nesvarbu, ar tai vadinama psichologine žala, psichologine trauma, pasekmèmis ir pan., teisès specialistai nori ir turi įrodyti priežastinị ryši tarp neteisèto veiksmo ir psichologinio sužalojimo. Deja, beveik neįmanoma griežtai nuspręsti dèl pasekmių priežastingumo, jei nustatoma poliviktimizacija. Šiame straipsnyje pateikiamos kelios teorinès poliviktimizacijos sampratos ir pabrěžiamos pasekmès, ị kurias reikia atsižvelgti, atliekant smurto tyrimus ir klinikinius bei (arba) psichiatrinius ar klinikinius aukų vertinimus. Trumpai aptarta Latvijos teisinè sistema ir praktinès teismo psichologinès bei teismo psichiatrinės ekspertizès problemos.

Adresas susirašinėti: egliitis.raitis@gmail.com

Gauta 2020-10-09 